\title{
Glaxo's new acquisition signals Biogen retreat from Europe
}

London

ONCE-PROUD multinational Biogen, the biotechnology company with bases at Geneva and Cambridge, Massachusetts, but with its registered office in the Netherlands Antilles, almost withdrew from Europe last week with the sale of its Geneva laboratory to Glaxo, the Britishbased pharmaceutical company. Biogen retains an interest in Bioferon, a joint venture in West Germany, and in a protein engineering laboratory in Belgium, but is otherwise concentrated in the United States.

This development has been driven by financial considerations, especially by Biogen's high ratio of operating costs to income during the past three years. The Geneva laboratory was the first of the company's research facilities. It has been sold to Glaxo for an undisclosed sum, but as a going concern. Glaxo will take over the existing staff of about 100 , together with responsibility for two products now in clinical trials (interleukin-2 and GPD-6) and worldwide market rights except in Japan and some neighbouring countries.

Glaxo says openly that its objective is to make faster progress in the development of new pharmaceutical products than would otherwise be possible. A spokesman estimated last week that the Geneva laboratory would put the company three years further ahead than would have been possible by internal growth.

The company plans to keep the Geneva laboratory as a separate facility, but the research programme will be set by $\mathrm{Dr}$ Allan Williamson, who left his post as a Glasgow professor to become director of scientific research at Glaxo.

Among drug companies, Glaxo has recently been among the most profitable. In the financial year to the end of June 1986 , its pre-tax profits were $£ 611$ million on sales of $£ 1,400$ million.

\section{French lose medical imaging capability}

\section{Paris}

In a deal that has caused concern among French medical researchers, the nationalized electronics company, Thomson, last week exchanged its medical imaging subsidiary, CGR (Companie Générale de Radiologie), for the domestic electronics division of the United States' General Electric. Some opponents of the agreement feel that the loss of CGR will bring to an end the previous close involvement of French medical researchers and practitioners in the design and manufacture of specialist radiological equipment.

CGR and its subsidiaries specialize in the therapeutic use of radiation and supply 60 per cent of radiological equipment found in French hospitals. For several years, research teams from INSERM (Institut National de la Santé et de la Recherche Médicale), France's principal medical research body, have contributed marketable ideas to CGR, while also being major clients. In 1985, INSERM and the Centre National de la Recherche Scientifique (CNRS) ordered a multi-milliondollar cyclotron from CGR for their joint medical laboratory at Lyons, without calling for international tenders, so sure were they of its appropriateness.

CGR's involvement in radiology will continue under General Electric's control, but developments in magnetic resonance imaging and scanner technology will be transferred to the parent company, depriving France of its place in these newer markets.

\section{Europe agrees on car exhaust emissions}

\section{London}

An agreement reached last month on car exhausts in Europe looks set to become a test case to clear the air surrounding the European Economic Community's (EEC) decision-making process.

The directive setting limits for vehicle emissions had been stalled for two years because of opposition by Denmark, which sought stricter standards like those in the United States. But under new EEC voting provisions designed to speed up decisions, the package was approved by eleven member states, overruling Denmark.

Denmark is now expected to adopt tougher standards within its own borders, allowed under the new voting rules on environmental protection grounds. But this would create a barrier to the free trade of vehicles, and the whole issue is likely to be taken by the EEC to the European Court of Justice as a test case.

The directive adopted last week divides vehicles into three categories, based on engine size; targets for large, medium and small cars respectively are 45,30 and 25 grammes per test for carbon monoxide (compared to 16 in the United States); 15, 8 and 6.5 for hydrocarbons and nitrogen oxides (4.6 in the US). The relatively lax standards for smaller cars leave the door open for lean-burn engine technology.

The European Parliament is expected to approve the vehicle emissions package within the next few months, but prolonged legal wrangling could block the road to implementation.
Kathy Johnston

\section{Reagan espouses superconductors}

\section{Washington}

LIKE a commander-in-chief giving a pep talk to his troops as they prepare for battle, President Ronald Reagan, flanked by his Secretaries of Defense, State and Energy as well as his science advisor and the director of the National Science Foundation, told participants in the special Federal Conference on the Commercial Applications of Superconductivity that they were "among the pioneers carrying on [the] American dream into the future." The president also used the occasion to announce plans for a legislative package aimed at "preserving the competitive advantage of US industries" in the superconductivity field.

By bringing along his top cabinet officers, President Reagan appeared to underscore the importance his administration attaches to the commercial potential of the new superconducting materials. (An alternative explanation might be that he intended to draw attention away from the testimony of Attorney General Edwin Meese before the Congressional committee investigating the Iran-Contra affair.) Although the discoveries about superconductors have been coming from laboratories all over the world, the conference definitely had an "America first" flavour. Foreign participants were excluded from attending, although the foreign press was allowed to cover the event.

After a brief scientific session where Angelica Stacy of the University of California at Berkeley, Paul Chu of the University of Houston and Robert Schrieffer of the University of California at Santa Barbara discussed the brief history of the new generation of high-temperature superconductors, the conference turned to how these new materials might be used for industry.

President Reagan told the conference that he will propose legislation modifying antitrust laws so that US industry could cooperate in developing applications for the superconductors. The president would also like to see greater protection for proprietary information now available to all under the Freedom of Information Act. The administration also intends to modify the patent process to help improve competitiveness in superconductivity.

These legislative changes are part of an 11-point superconductivity initiative that will include a "Wise Men's" advisory group on federal policies relating to research and commercialization of superconductors. Other points include federal grants for new material processing schemes and $\$ 150$ million to the Department of Defense for superconductor research over the next three years. 